\title{
Cervical Cancer Risk Factor: HPV Infection Among Indonesian Urban Women
}

\author{
Sarwo Handayani ${ }^{*}$, Rita Marleta Dewi ${ }^{1}$, Holy Arif Wibowo ${ }^{1}$, \\ Frans Dany ${ }^{1}$, Natalie Laurencia Kipuw ${ }^{1}$, Rosa Adelina ${ }^{1}$, Kindi Adam ${ }^{1}$, \\ Nanang Yunarto ${ }^{1}$, Sri Idaiani ${ }^{2}$, Antonius Yudi Kristanto ${ }^{3}$
}

\author{
${ }^{1}$ Center for Research and Development of Biomedical and Basic Health Technology, NIHRD, Jakarta, Indonesia \\ ${ }^{2}$ Center for Research and Development of Health Resources and Services, NIHRD, Jakarta, Indonesia \\ ${ }^{3}$ Center for Research and Development of Public Health Effort, NIHRD, Jakarta, Indonesia \\ *Corresponding author. E-mail: menik25@gmail.com
}

\begin{abstract}
Cervical cancer is the fourth rank of women cancer in the world. The major cause of that cancer is Human Papilloma Virus, with the globally prevalence around $11.7 \%$ in 2010 . In Indonesia, there is limited data of HPV infection. The aim of the study was to provide the national data of HPV infection among Indonesian urban women. The study was conducted in 2016-2017 in 34 provinces and 76 districts. Samples were cervical swabs collected from women who met inclusion criteria. Cervical swabs were screened for HPV infection using the hybrid capture method, then data were analyzed as descriptive. A total of 35,408 cervical swab specimens from 34 provinces in Indonesia were tested. The prevalence of HPV infection among urban women was 5.2\%, mostly $(85 \%)$ as high-risk HPV group. The highest prevalence of HPV infection was discovered among women, either aged 35-44 years old (5.9\%), had educational background of college (5.7\%), working as an employee (6.8\%) or already divorced (10.4\%). The discovery of HPV infection among Indonesian urban women which commonly from the high risk group is potential for cervical cancer. Therefore, the preventive dealings such as early detection and HPV vaccination are required to control the HPV infection in Indonesia.
\end{abstract}

Keywords: HPV, infection, Indonesia

\section{INTRODUCTION}

Cervical cancer is the fourth most common cancer among women worldwide. The major cause of cervical cancer is the Human Papilloma Virus (HPV) [1,2]. Several studies showed that the prevalence of HPV infection varies considerably in some countries. However, globally the prevalence of HPV infection was estimated at $11.7 \%$ in 2010 [3]. In Indonesia, data of cervical cancer and the prevalence of HPV infection is very limited. Estimated 95.9 million for women aged $\geqslant 15$ years old have cervical cancer risk with an incident 17 per 100.000 inhabitants per year [4]. Study in the hospital showed that among 10 cervical cancer patients with IIB-IIIB stadium nearly 91.7\% were HPV positive [5], while in the community of women aged 15-70 years old in three cities of Jakarta, Tasikmalaya, dan Bali, the HPV prevalence exposed much lower of $11.4 \%$ [6]. Indonesia has a considerable population and nearly a half of the population are women [7], who have a risk of being infected HPV. The aim of the study was to provide the national data of HPV infection among Indonesian urban women.

\section{METHOD}

The design of the study was a laboratory-based crosssectional, subsample of non-communicable disease research of breast tumors and pre-cervical cancer lesion was conducted in 2016. Ethical approval was obtained from the ethic committee of National Institute of Health Research and Development (NIHRD), no LB 02.01/5.2/KE/154/2016.

A purposive sampling method was designed by Center Bureau of Statistic (BPS) from 34 provinces and 76 districts in Indonesia, which represented the national data. All respondents were selected based on inclusive criteria: women aged 25-64 years old, had marital or sexual intercourse history, living in urban area and willing to give informed consent. Those with serious illness, trouble in communicating, and pregnancy were excluded from this study. The selection of urban areas was regarding the feasibility of specimen collection and also transportation. Cervical swab specimens from those respondents were gathered at selected primary health centers, then transferred in special media to the NIHRD laboratory, Jakarta. Cervical swab specimen was taken by trained doctors or midwives and was done in a local community health center 
(Puskesmas), which fulfilled the required facility. Hybrid capture (®Qiagen) (8) method based on DNA hybridization principle was performed to screen HPV positive and differentiate the high and low risk HPV, according the kit manual. This method is based on the principle of viral DNA denaturation and the complementary chain of DNA and probe RNA hybridization, resulting in a form of complex DNA-RNA hybrid. The quantitative result was interpreted qualitatively using cut-off points determined by the standard, the positive control (marked by the formation of HPV DNA-RNA hybrid complex), and also the negative one. The result then was combined with the health variables obtained from the questionnaire. The data were analyzed descriptively using SPSS version 15, weighed and represented as nationwide prevalence.

\section{RESULTS AND DISCUSSION}

A total of 35.408 specimens were collected from 34 provinces in Indonesia. Figure 1 shows the specimen distribution. The number of the specimen from Java Island (West, Central and East Java Provinces) was the highest. Meanwhile, the least specimen number was from West Sulawesi, West Papua, and Riau Island. The national HPV prevalence among Indonesian urban women was 5.2\%, mostly caused by high risk group (3.5\%), and then followed by mix group of high and low risk HPV $(0.9 \%)$, and the last by low risk group $(0.8 \%)$, as described on Table 1 .

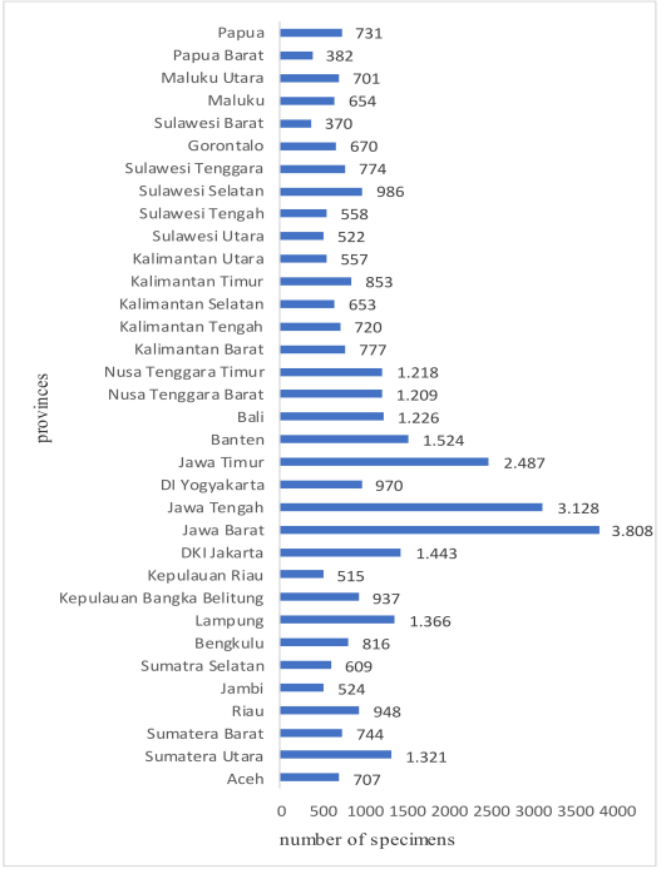

Figure 1. Specimen Distribution by provinces in Indonesia
Table 1. The percentage of HPV infection among Indonesian urban women based on the risk groups

\begin{tabular}{cc}
\hline HPV Risk Groups & $\%$ \\
\hline HPV Positive & 5.2 \\
\hline - High Risk & 3.5 \\
- Low Risk & 0.8 \\
- Mix high and low risk & 0.9 \\
HPV negative & 94.8 \\
\hline
\end{tabular}

Table 2 shows the HPV prevalence by socio-demographic variables. According to age groups, most of the respondents and also the HPV prevalence were woman at 35-44 years old. Based on education, occupation and marital status, the peak proportion of HPV were from university or diploma, non-working women or a housewife, an employee and divorced women respectively. Moreover, the quite similar percentage of HPV infection was discovered among all household poverty index groups.

Table 2. Prevalence of HPV Infection among Indonesian Urban Women by Socio-demographic Characteristics.

\begin{tabular}{|c|c|c|c|c|c|c|c|}
\hline \multirow{2}{*}{$\begin{array}{c}\text { Characteristic } \\
\text { Age Group (Years old) }\end{array}$} & \multirow{2}{*}{$\begin{array}{c}\mathrm{n} \\
\text { weighted }\end{array}$} & \multirow{2}{*}{$\begin{array}{c}\text { HPV Positive } \\
(\%)\end{array}$} & \multicolumn{2}{|c|}{$95 \% \mathrm{CI}$} & \multirow{2}{*}{$\begin{array}{c}\text { HPV } \\
\text { Negative } \\
\end{array}$} & \multicolumn{2}{|c|}{$95 \% \mathrm{CI}$} \\
\hline & & & & & & & \\
\hline & 10,916 & 5.7 & 5.0 & 6.6 & 94.3 & & 95.0 \\
\hline $35-44$ & 11,878 & 5.9 & 5.4 & 6.5 & 94.1 & 93. & 94.6 \\
\hline $45-54$ & 8,200 & 4.5 & 4.0 & 5.1 & 95.5 & 94. & 96.0 \\
\hline $55-64$ & 4,414 & 3.5 & 2.8 & 4.4 & 96.5 & 95. & 97.2 \\
\hline \multicolumn{8}{|l|}{ Education } \\
\hline Uneducated & 889 & 3.4 & 2.2 & 5.3 & 96.6 & 94. & 97.8 \\
\hline Not finish elementary & 2.515 & 5.6 & 4.4 & 7.1 & 94.4 & 92. & 95.6 \\
\hline Elementary School & 8.514 & 4.6 & 4.0 & 5.2 & 95.4 & 94. & 96.0 \\
\hline Junior high school & 7,636 & 5.4 & 4.7 & 6.3 & 94.6 & 93. & 95.3 \\
\hline Senior High School & 12,273 & 5.5 & 4.9 & 6.2 & 94.5 & 93. & 95.1 \\
\hline University/diploma & 3.583 & 5.7 & 4.6 & 7.0 & 94.3 & 93. & 95.4 \\
\hline \multicolumn{8}{|l|}{ Occupation } \\
\hline king/housewi & 22.685 & 5.0 & 4.6 & 5.5 & 95.0 & 94. & 95.4 \\
\hline & & & & & & 91. & \\
\hline & 4,1 & & 3.8 & & & 94. & \\
\hline & 3,1 & & 3.9 & 6.0 & 95.1 & 94. & 96.1 \\
\hline Others & 1,225 & 6.5 & 4.7 & 8.7 & 93.5 & 91. & 95.3 \\
\hline \multicolumn{8}{|l|}{ Marital Status } \\
\hline Not married & 64 & & 2.5 & 23. & 92.2 & 76. & 97.5 \\
\hline & 32,514 & & 4.7 & 5.4 & & 94. & 95.3 \\
\hline & & 10.3 & 7.8 & 13. & & 86. & 92.2 \\
\hline & 1,901 & 5.7 & 4.5 & 7.5 & 94.3 & 92. & 95.5 \\
\hline \multicolumn{8}{|l|}{ Household poverty } \\
\hline Low & 6,639 & 5.3 & 4.5 & 6.0 & 94.7 & 94. & 95.5 \\
\hline Lower middle & 9.285 & 5.2 & 4.5 & 5.9 & & 94. & 95.5 \\
\hline $\mathrm{M}$ & 5.4 & 5.3 & 4.5 & 6.2 & & 93. & 95.5 \\
\hline & 7,227 & 5.3 & 4.6 & 6.2 & 94.7 & 93. & 95.4 \\
\hline High & 6.815 & 5.2 & 4.6 & 6.1 & 94.8 & 93. & 95.4 \\
\hline Indonesia & 35,408 & 5.2 & 4.9 & 5.6 & 94.8 & 94. & 95.1 \\
\hline
\end{tabular}

*Divorced refers to women separated from her spouse who was still alive at the time of marriage dissolution, widow denotes to women who lost her spouse by dead

The result of this HPV screening was descriptive, thus not analyzing further the causal relationship with the characteristic determinants. The HPV prevalence is diverse among nation and regions. Our results report that there were $5.2 \% \mathrm{HPV}$ cases in Indonesia, about half the percentage of worldwide HPV cases in 2010 (11.7\%), and less than those reported in Sub-Saharan Africa, East Europe, and Latin America. However, the dominancy of high-risk HPV group might rise an attention for causing cervical cancer later. In Asia, a meta-analysis from $79 \mathrm{HPV}$ studies that used PCR as its diagnostic method revealed that $14.4 \%$ of HPV infection was found in women with normal histology,(9) almost similar to the percentage of the same cases in 
our gratitude to the respondents who have been willing to take part in our study and members of the research team who have assisted in the examination and data analysis.

\section{REFERENCES}

[1] Prat J, Franceschi S. World cancer report 2014. In: World Health Organization [Internet]. 2014. p. 465 .

[2] Walboomers JMM, Jacobs M V., Manos MM, Bosch FX, Kummer JA, Shah K V., et al. Human Papillomavirus Is a Necessary Cause of invasive cervical cancer worldwide. J Pathol. 1999;19(189):12-9.

[3] Bruni L, Diaz M, Castellsagué X, Ferrer E, Bosch FX, de Sanjosé S. Cervical Human Papillomavirus Prevalence in 5 Continents: Meta-Analysis of 1 Million Women with Normal Cytological Findings. J Infect Dis [Internet]. 2010;202(12):1789-99.

[4] ICO. Human Papillomavirus and Related Diseases Report INDONESIA. 2017;(July).

[5] Widyorini LH, Andrijono BS. Hubungan antara Genotyping DNA Human Pappillomavirus (HPV) dengan Respons *Main author Terapi Radiasi pada Adenokarsinoma Serviks. Indones J Cancer. 2015;9(1):13-22.

[6] Vet JNI, De Boer MA, Van Den Akker BEWM, Siregar B, Lisnawati, Budiningsih S, et al. Prevalence of human papillomavirus in Indonesia: A population-based study in three regions. Br J Cancer. 2008;99(1):214-8.

[7] Central Bureau of Statistic. Population Percentage by Province and Gender. https://www.bps.go.id/dynamictable/201 8/03/20/1288/persentase-penduduk-men urutprovinsi-dan-jenis-kelamin-2009-20 18.html.

[8] Gmbh ENQ, Stra Q. Detection Kit Handbook Sample \& Assay Technologies QIAGEN Sample and Assay Technologies. 2010;(April).

[9] Bao YP, Li N, Smith JS, Qiao YL, Tan J, Liu J, et al. Human papillomavirus type distribution in women from Asia: A meta-analysis. Int J Gynecol Cancer. 2008;18(1):71-9.

[10] Kantathavorn N, Mahidol C, Sritana N, Sricharunrat T, Phoolcharoen N, Auewarakul
We would like to thank the Center for Research and Development of Biomedical and Basic Health Technology for financing and facilitating this research. We also express 
$\mathrm{C}$, et al. Genotypic distribution of human papillomavirus (HPV) and cervical cytology findings in 5906 Thai women undergoing cervical cancer screening programs. Infect Agent Cancer. 2015;10(1):1-9.

[11] Baloch Z, Yasmeen N, Li Y, Ma K, Wu X, Yang S, et al. Original article Prevalence and risk factors for human papillomavirus infection among Chinese ethnic women in southern of Yunnan, China. 2017;1(3):325-32.

[12] Kenney JW. Ethnic differences in risk factors associated with genital human papillomavirus infections. J Adv Nurs. 1996;23(6):1221-7.

[13] Silva KC, Luiza M, Rosa G, Moyses N, Afonso LA, Oliveira LHS, et al. Risk factors associated with human papillomavirus infection in two populations from Rio de Janeiro, Brazil. 2009;104(September):885-91.

[14] Kahn JA, Lan D KR. Sociodemographic Factors Associated With High-Risk Human Papillomavirus Infection. 2007;110(1):87-95.

[15] Okunade KS, Nwogu CM OA and AR. Prevalence and risk factors for genital high-risk human papillomavirus infection among women attending the out- patient clinics of a university teaching hospital in Lagos, Nigeria. Pan Afr Med J. 2017;28(227):1-7.

[16] Leyh-Bannurah SR, Prugger C, De Koning MNC, Goette H, Lellé RJ. Cervical human papillomavirus prevalence and genotype distribution among hybrid capture 2 positive women 15 to 64 years of age in the Gurage zone, rural Ethiopia. Infect Agent Cancer. 2014;9(1):1-9. 